\title{
1. On new Genera and Species of Araneidea.
}

By the Rev. O. P. Cambridge, M.A., C.M.Z.S., \&c.

[Received April 29, 1882.]

\section{(Plates XXIX.-XXXI.)}

Of the sixteen species of Spiders described on the present occasion, two are from Caffraria, sent to me by Mr. Mansel Weale; one from St. Helena, received from Mr. Melliss some years ago; two from Ceylon, contained in the fine collection made for me by Mr. G. H. K. Thwaites; and the rest (11 species) from a collection made on the Amazons by Professor Traill. All are, so far as I am able to ascertain, new to science, excepting the Spider from St. Helena, erroneously included by myself (P. Z. S. 1869 , p. 538, pl. xlii. fig. 6) in the genus Olios. The example from which the description and figures $(l . c$. $)$ were made was a very misleading one, having been pinned and dried, some important generic parts injured, and its legs extended laterally, in what I find since to be a quite unnatural position. Specimens of this Spider received more recently have convinced me that a new genus of Drassida must be established for its reception. Eight other new genera are also here characterized, belonging to the families Drassida, Theridiida, Poltida, and Salticida.

One other point of interest only need be noted here; and that is the discovery, for the first time in South America, of a species of the curious four-eyed genus Miagrammopes, Cambr. (posteà, p. 435. The genus was first characterized from Ceylon (Linn. Soc. Journ. x. p. 398). Since then it has been found at Sydney, N. S. W., Rodriguez, Zanzibar, and now also (2 species) in Caffraria (posted, pp. 436,437$)$.

\section{Fam. DRASSIDE.}

Xeropigo, g.n. (nom. propr.).

Cephalothorax broad-oval, truncated in front. The lateral marginal constrictions are strong; and the profile-line forms a tolerably even curve from the upper part of the clypeus to the posterior margin, with a slight dip or depression at the thoracic junction. The height of the clypeus is rather less than half that of the facial space.

Eyes 8, in two curved rows, the conrexity of the curve directed backwards; the anterior row shortest; they are of moderate size; those of the fore central pair considerably the largest of the eight.

Legs moderately long, not differing greatly in length, but strong, $4,1,2,3$. They are furnished with hairs, bristles, and spines; those beneath the tibiæ and metatarsi of the first and second pairs are disposed in two longitudinal parallel rows, but irregularly disposed on the third and fourth pairs. Beneath the tarsi of the first

Proc. Zool. Soc.-1882, No. XXIX. 
and second pairs is a not very dense scopula; and the terminal claws are two, apparently not denticulated; and beneath them is a short, dense, compact claw-tuft.

Falces long, powerful, and vertical, with a very strong fang.

Maxilla strong, curved over the labium, convex on their exterior surface, rounded on their outer sides, obliquely truncated at their extremities on the inner side, and with a strong indentation on their inner side, just above the level of the apex of the labium.

Labium short and somewhat oval ; sides curved, and apex slightly hollowed.

Sternum short, oval, truncate before, pointed behind.

Abdomen oblong-oval, somewhat subcylindrical; spinners short, compact, those of the inferior pair strongest.

\section{Xeropigo tridentiger, Cambr. (Plate XXIX. fig. 1.)}

Olios tridentiger, Cambr. P. Z. S. 1869, p. 538, pl. xlii. fig. 6 ; and E. Simon, Actes de la Soc. Linnéenne de Bordeaux, vol, xxxiv. ([4] vol. iv.) p. 299.

Length of the adult male $4 \frac{1}{2}$ to 6 lines.

The cephalothorax is of a dark reddish-brown colour, deepening to black on the caput and falces, and pretty densely clothed with short greyish pubescence.

The eyes of the posterior row are nearly equally separated, the interval between those of the hind central pair being perhaps rather the largest. The four central eyes form very nearly a square, and the intervals between those of the anterior row are small, but equal; the fore centrals are much the largest of the eight.

The legs are yellow, clothed with greyish-yellow pubescence and other hairs, and the spines are tolerably long and strong.

The palpi are rather short, and of a redder yellow-brown than the legs, deepening to dark red-brown on the radial and digital joints. The radial is rather longer than the cubital joint, and is a little produced at its extremity in front, with several somewhat dentiform spines and projections issuing from the extremity of its outer and under sides; three of these are close together on the outer side, two being sharp-pointed and the lower one enlarged and obtuse at its extremity ; underneath the joint is the fourth, which is pale-coloured, and furnished with a strong, red-brown, curved (somewhat sinuous) tapering spine, whose point is close to the base, on the outer side of the digital joint. The digital joint is large and of a long-oval form, slightly prominent near the middle on the outer margin. The palpal organs are not very prominent or complex, but have several spines and spiny processes near their fore extremity.

The falces have their surface roughened with numerous minute tubercular granulations, and are covered with strong bristly hairs.

The maxilla and labium are of a deep blackish red-brown colour; and the sternum is of a lighter hue.

The abdomen is pretty densely clothed with short hairs of a 
greyish-yellow and darker hues, and with numerous prominent bristly ones.

Along the middle of the fore half of the upperside is a largish paler yellow-brown somewhat oblong marking, enlarging to its hinder extremity, where it has three divergent points. On the middle of the hinder part of this marking is a longitudinal darkbrown patch; following this, towards the spinners, are several indistinct, curved, pale transverse lines. The underside is pale yellowish brown.

This species was founded upon a Spider received in a dried and pinned state from Mr. T. J. Melliss, by whom it was captured in the island of St. Helena. The legs were set out laterally ; and the various structural characters of the Spider presenting a striking agreement with some of the Thomisida represented by the genus Olios, led me at the moment to include it in that genus. Subsequently, however, I received a fine well-conditioned example in spirit of wine, and at once saw that it was not a laterigrade Spider at all, but belonged probably to some unknown genus of Drassidre. This is also confirmed by the opinion of Mons. Simon, to whom I lately sent it for examination, its nearest allies being probably the genus Clubiona.

\section{Arachosia, g. n. (nom. propr.).}

Cephalothorax oval ; lateral marginal constrictions well marked; anterior portion of caput (at the insertion of the falces) truncated in a straight line, the corners being a little prominent; profile-line even and almost level, very slightly highest at the beginning of the posterior slope.

Eyes small, and not greatly different in size, in two transverse rows, of which the anterior (or lower one) is nearly straight, and the posterior very strongly curved; the convexity of the curve directed backwards. The eyes of the lateral pairs are pretty widely separated.

Legs not very long, strong, 4, 3, 1, 2 (3, 1, and 2 being very nearly of equal length), armed with hairs and slender spines; terminal tarsal claws two, with claw-tuft and scopula (not dense) beneath the tarsi and metatarsi.

Falces moderately long and strong, prominent at their base in front, and a little directed forwards.

Maxilla rather long, straight, sides nearly parallel, rounded on the outer sides at their extremity, and obliquely truncated on the inner sides.

Labium about half the length of the maxillæ, oblong, and rounded at apex.

Sternum oval, pointed behind.

Abdomen elongate-oval, of a somewhat cylindrical form, fitting fairly up to but not over the thorax; at the middle of the underside is a largish transverse curved slit or aperture, leading doubtless to a respiratory apparatus. This aperture is covered with 
numerous strong hairs. Another fold in the epidermis, a little way in front of the spinners, appears to indicate also an additional aperture of the same nature. Spinners short, compact, those of the inferior pair strongest. This genus is allied to Anyphana.

Arachosia anyphenoides, sp. n. (Plate XXIX. fig. 2.)

Adult female, length $3 \frac{1}{2}$ lines.

The colour of the cephalothorax (which is thinly clothed with short silky greyish hairs) is brownish yellow, tinged with dull orange. A broad central brown band runs from the eyes to the posterior extremity; and there is a submarginal thoracic line of a deeper red-brown hue.

The eyes are seated on small black spots, the outer ones of the anterior row are smallest, and the interval between those of the hind central pair is considerably greater than that between each and the hind lateral next to it. The relative position of the eyes of the anterior row is also nearly similar, and the hind lateral (on each side) about equally separates the hind central and fore lateral eyes.

The legs are of a clearer yellow colour than the cephalothorax, speckled with dark red-brown, chiefly on the fore parts and outer sides of the femora. The spines are long and rather slender; beneath the tibiæ of the 1st and 2nd pairs of legs are 4 (in two pairs), and another pair beneath the base of the metatarsi ; those on the 3rd and 4th pairs are more numerous and irregularly disposed. The scopula beneath the tarsi and metatarsi is densest on the 1st and 2 nd pairs.

The palpi are slender and moderately long, yellow, and furnished with numerous long spine-like bristles. Each palpus ends with a small curved claw.

The maxilla and sternum are similar in colour to the legs; the labium tinged with yellow-brown.

The abdomen is of a dull clay-vellowish hue, clothed with short greyish silky hairs on the pale portions. A broad, longitudinal, central dark-brown band (slightly denticulate on its margins towards the hinder part) occupies the upperside, which has also on each side a narrow, lateral, somewhat broken stripe of a similar hue. The underside is also marked with a broad, slightly tapering, central longitudinal brown band, on which are numerous pale strong hairs near the middle, over and around the central spiracular opening (mentioned in the generic diagnosis). The genital aperture is rather large, somewhat horseshoe-shaped, and of rery characteristic structure.

A single example was contained in Mr. Traill's Amazon collection.

Fam. TH E R I II IDE.

Coleosoma, g. $n$.

Nearly allied to Sphecozone, Cambr., but easily distinguished by the more depressed caput, and especially by the formation of the 
fore part of the abdomen, which is of a cylindric form, drawn out into a kind of sheath, into which the distinct pedicle uniting the cephalothorax and abdomen is inserted; the cuticle of this sheath runs back a long way beneath the abdomen, and includes the spiracular plates, the openings into the spiracles being thus unusually approximated to the hinder part of the abdomen.

The cephalothorax is small, oval, and without lateral marginal constriction at the caput.

Legs moderately long and very slender, furnished with hairs and a very few fine spines, $1,4,2,3$.

Eyes very small, rather closely grouped, and placed as in Neriene. Clypeus prominent.

Falces rather small, straight and vertical.

Maxilla strongly inclined to the labium, over which they almost meet at their extremities.

Labium very short, and somewhat rounded at the apex.

Coleosoma blandum, sp. n. (Plate XXIX. fig. 3.)

Adult male, length 1 line.

The cephalothorax, falces, maxillæ, labium, and sternum are of a yellow-brown colour, more or less suffused with dusky brown. The profile of the thorax and caput forms a slight curve to the eyes; the height of the clypeus (which is prominent) exceeds half that of the facial space.

The legs are pale yellow, a small portion at the posterior extremity of the tibiæ, and at the anterior extremity of the metatarsi, of those of the fourth pair being of a brownish hue.

The palpi are of moderate length, and of a dark suffused yellowishbrown colour. The cubital joint is strong, somewhat curved, and obtuse at its fore extremity, near which issues a single sinuous strongish bristle; the radial joint, which is shorter, is articulated to the cubital somewhat sideways, being directed outwards from it, much like that of some species of Theridion, and of a broad spreading form at its extremity. The digital joint is large, oval, and with a strong lobe on its inner side; the palpal organs are prominent and complex, with a large, strong, circularly curved tapering spine at their outer side.

The abdomen is of a cylindric form, strongly constricted across the upperside near the middle; the peculiar sheath-like form of its anterior extremity has been noticed above; this part is yellowbrown; the rest is nearly black, with a very large, pale, dull yellowish marking on the sides, extending to the underpart. The posterior extremity projects over the spinners, and is obtusely rounded and prominent.

A single example of this very peculiar and delicate little Spider was sent to me, among others, some years ago from Ceylon by Mr. G. H. K. Thwaites. It combines characters of Neriene, Linyphia, Theridion, and Sphecozone. 
Genus Sphecozone ${ }^{1}$, Cambr.

Sphecozone nigra, sp. n. (Plate XXIX. fig. 4.)

Adult male, length 1 line.

The whole of the fore part of this Spider is deep brown-black, the falces and the extremities of the legs being rather the brownest; and the abdomen is black.

The general form and structural characters are very similar to those of $S$. rubescens, Cambr., the type of the genus; the Spider, however, is smaller, and differs totally in colours and in the structure of the palpal organs. Several bristly hairs spring from the upperside of the caput, some from the ocular area curving towards and meeting others (stronger ones) curving towards them from the occiput.

The palpi are of moderate length ; the radial joint is of a somewhat similar cup-shape to that of $S$. rubescens, but not nearly so large or developed; the fore extremity on the upperside is produced and prominent, terminating in a bifid form. The digital joint is large and oval, but rather strongly and irregularly indented on the outer side towards its base. The palpal organs are bighly developed, prominent and complex, consisting of several very marked corneous spines and processes; one of the spines is of very great length, black, slender, tortuous and convoluted, ending in a long hair-like point,

Received in Mr. Traill's Amazon collection.

\section{Аснаa, g. n.}

The little Spider on which this genus is based is closely allied to Theridion, Walck. ; but the large size and prominence of the fore central pair of eyes, as well as the obtusely humped posterior extremity of the abdomen, appear to exclude it from that genus. The eyes also (among other characters) separate it from Thwaitesia, Cambr., and Chrysso, ejusd.

In the only example examined the legs of the fourth (or posterior) pair were wanting; but from the lengths and proportions of the three other pairs I should judge their relative lengths to be $1,4,2,3$. The legs are rather slender and tolerably long, furnished with hairs only, excepting three or four spines beneath the femora of those of the first and second pairs; each tarsus ends with three claws.

Maxillae and labium as in Theridion.

Cephalothorax short and broad, with little or no lateral marginal constriction at the caput.

Abdomen short, somewhat cylindric in form, bluntly produced, but not to any great extent, at its posterior extremity on the upperside; probably the female would present this character in a much stronger degree.

Achea insignis, sp. n. (Plate XXX. fig. 5.)

Adult male, length 1 line.

The whole of the fore part of this Spider is of a clear reddish P. Z. S. 1870 , p. 733 , pl, xliv. fig. 3 . 
orange-yellow colour, excepting a large black central spot on the sternum. The sides of the thorax are considerably rounded, and the normal indentations marking off the caput from the thorax are strongly marked. Along the median line of the caput are several bristly hairs directed forwards.

The eyes are very unequal in size for this family; those of the fore central pair are much the larger, and form a line longer than those of the hind central pair, and have their visual axis directed forwards and outwards; these last are rather wider apart than each is from the hind lateral on its side.

The palpi are short, the cubital and radial joints exceedingly so. The digital joint is large, and of an abnormal form, somewhat rounded at its base; it has its fore extremity considerably produced into a rather narrow and tapering form; its extremity is furcate, one point of the furcation being longer than the other. The palpal organs are rather complex and highly developed; connected with them is a tortuous, somewhat convoluted, pale-yellowish tapering spine of immense length; and its long slender filiform point extends very prominently outwards. One corneous process of the palpal organs is long, prominent, and tapering, and has its extremity, which projects outwards, notched.

The abdomen is of a pale-yellowish luteous hue, thinly clothed with hairs; its upper posterior extremity has a large black spot, on each side of which below (towards the spinners) is another; two others are placed (one on each side) towards the fore part of the upperside; and a sixth is underneath, just in front of the spinners. The spinners are very short and compact.

A single example of this remarkably distinct species was contained in Mr. Traill's Amazon collection.

Chrysso, g. n.

Cephalothorax much like that of Theridion, small, somewhat depressed, short-oval in form, with very slight lateral marginal constriction at caput.

Eyes as in Theridion.

Legs moderately long, slender, 1, 4, 2, 3, furnished with hairs only.

Falces small, not very strong, straight and vertical.

Maxilla of moderate size, pointed at their inner extremities, and inclined towards the labium, which is short and of a somewhat semicircular form.

Abdomen large, the posterior extremity (particularly in the female) produced into a long and tapering continuation, varying, however, in its length in different individuals.

This genus is nearly allied to Argyrodes, appearing to form a sonnecting link between it and Theridion.

Chrysso albomaculata, sp. n. (Plate XXX. fig. 6.)

Adult male, length $1 \frac{1}{2}$ line; female, $2 \frac{1}{2}$ lines.

The whole of the fore part of this pretty little Spider is of an orange- 
yellow colour; the two terminal joints of the palpi (in the female) black-brown, and the tarsi of the legs tinged with dark brown.

The palpi are short and slender, excepting the digital joints of those of the male, which are very large and of a dark yellow-brown hue; the palpal organs are highly developed and complex, with a closely connected, long, rather strong, sinuously curved black spine, whose origin is near their centre, and its long, filiform, slender point ends near their extremity. The length of the digital joint is nearly equal to that of all the rest of the palpus; the radial joint is very short and spread out, the cubital equally short but of a somewhat nodiform shape.

The abdomen of the female has its posterior extremity drawn out into an obtuse point, the distance of which from the spinners is in some cases equal to that from the spinners to the fore extremity of the upperside of the abdomen, while the abdomen of the male has the posterior extremity only slightly and very obtusely produced. The colours and markings are similar in both sexes, the groundcolour being of a dull luteous clay-yellow, with a long, tapering, white, central longitudinal band on the upperside, broken up into more or less separated blotches and spots, and a longitudinal row of large white blotches on each side. The posterior extremity is tipped with black; and there are also four rather suffused black markings near the upperside, one on each side towards the fore part, and the other two near the beginning of the produced portion. The genital aperture of the female is of a simple, somewhat semicircular form.

Examples of both sexes were contained in Mr. Traill's Amazon collection.

\section{Chrysso? quadrata, sp. n. (Plate XXX. fig. 7.)}

Adult female, length 2 lines; adult male, $1 \frac{1}{2}$ line.

It is with some hesitation that $\mathbf{I}$ include this Spider in the above genus; it differs from $C$. albomaculata (the type species) in a more raised ocular region and a slightly different relative size of the four central eyes. The labium also is broader at the apex.

The cephalothorax, falces, maxillæ, labium, and sternum are of a clear slightly orange-yellow colour ; the basal half of the femora of the legs is also of a similar hue, the remainder, with the tibiæ, tarsi, and metatarsi being dark, varying to a deep blackish red-brown. The radial and digital joints of the palpi are also dark brown.

The four central eyes do not differ much in size; they form a quadrate figure whose width is slightly greater than its length; taken in two rows, the eyes of each row are as nearly as possible equidistant from each other.

The legs are moderately long, 1, 4, 2, 3, slender, and furnished with hairs only.

The falces are of moderate length, straight, vertical or very nearly so.

The maxilla are rather long, pointed at their extremities, and inclined towards the labium. 
The labium is short, not half the length of the maxillæ, about as broad as long, and rounded at the apex.

The sternum is long, and of a triangular form.

The abdomen is large and of a quadrate form, being blunt-angular in front, behind, and on each side; the posterior extremity projects beyond the spinners, which (looked at in profile) form another somewhat angular prominence; the anterior portion projects greatly over the cephalothorax. The colour of the abdomen is yellow, generally appearing to fade to a somewhat clayey colour; on the upperside is a broad, more or less broken, longitudinal central white band, with some lateral blotches or patches of the same colour. The lateral and posterior angles are boldly tipped with black, and five brownish or black marks along the middle indicate the normal impressed spots.

The male is smaller than the female, and the abdomen is of a narrower form, the lateral angles being scarcely noticeable; but in colours and markings the sexes are similar. The palpi are short, the radial and cubital joints particularly so ; the digital joint is large, and has its extremities on the inner side considerably produced in a pointed form and somewhat bent; the convex sides of the digital joints (as is not unusual in some allied genera) are directed inwards towards each other. The palpal organs are tolerably compact but complex, and, though less developed, not much unlike those of $C$. albomaculata.

Numerous examples of this pretty Spider, but nearly all females, were contained in collections sent to me some years ago by Mr. G. H. K. Thwaites, from Ceylon. The genus is evidently nearly allied to Euryopis, Menge.

\section{Genus Thwaitesia, Cambr.}

Thwaitesia affinis, sp. $n$. (Plate XXXI. fig. 8 A.)

Adult female, length $2 \frac{1}{2}$ lines.

This Spider is very like Thwaitesia margaritifera, Cambr. (the type of the genus, found in Ceylon). The abdomen is of a similar dull luteous-yellowish hue, ornamented with numerous brilliantly shining white, pearly, silvery scale-like blotches; and it also has its posterior extremity produced upwards in a conical form, so that looked at sideways the abdomen is as nearly as possible an equilateral triangle. In the type (from Ceylon) the abdomen is much more produced. The legs are also rather stronger and shorter than in the type, and are armed with fewer distinct spines, while the hairs are stronger and of a more spine-like bristly nature. The colour of the legs is a dull orange, suffused with deep orange-brown at the far extremities of the tibiæ and metatarsi, a small portion of the base of the latter being also similarly suffused.

The ocular area (or rather the space within the eyes) is raised in a more convex form; and the genital aperture is smaller and of a totally different form.

Each tarsus (in both species) ends with a strongish, black, curved pectinated claw.

A single example in Mr. Traill's Amazon collection. 


\section{Thwaitesia? diversa, sp. n. (Plate XXXI. fig. 8.)}

Adult female, length 2 lines.

This Spider differs in some respects from the type of the genus, but whether sufficiently so to justify the formation of another genus for it appears to be uncertain as yet.

The normal indentations of the cephalothorax are less strong, and the eyes of the posterior row are equidistant from each other, and the height of the clypeus is equal to half that of the facial space; the legs also are shorter and rather stronger, and are furnished with hairs only, but these are strong and of a bristly and even somewhat spinous nature.

The maxillæ are very similar to those of the type; but the labium is distinctly hollowed at the apex.

The cephalothorax, falces, maxillæ, and labium are of a brightish orange-yellow brown hue; and the sternum is of the same colour, with a dusky patch near its fore extremity.

The legs are of a paler yellow hue; the fore extremities of the femora and tibiæ, with the genual joints and (more faintly) a portion near the middle of the femora and tibiæ of the first and second pairs, are red-brown, giving the legs an annulated appearance.

The abdomen is large, and has its posterior extremity produced into a strong but not very long hump. When looked at in profile, the distance from the spinners to the apex of the hump is rather less than that from the spinners to the fore extremity (on the upperside) of the abdomen. It is thinly clothed with hairs, and is of a pale dull luteous yellowish-brown colour. The posterior extremity of the hump is black; and in other parts along the middle, at the back and on the sides, there are blackish stripes, patches, and markings; one also underneath (between the spinners and the genital aperture) appears to contain a transverse slit, probably the opening into a portion of the breathing-apparatus; if this should prove to be so (of which I could not satisfy myself sufficiently), it would probably be a good reason for its separation into another genus. The genital aperture is nearly round, not large, but placed on a transverse oval area and surrounded outside again with a strong corneous-looking rim. The spinners are short and compact.

A single example in Mr. Traill's Amazon collection.

\section{Subfamily Phoroncidina.}

\section{Ogulnius, g. n. (nom. propr.).}

Cephalothorax abbreviated behind ; caput rather raised and produced, the ocular area including the whole of its anterior extremity; clypeus low, considerably less than half that of the facial space.

Eyes unequal in size, the four centrals largest, and forming a large trapezoid whose anterior side is much the shortest; the lateral pairs are placed obliquely on small tubercles, and the eyes of each are contiguous to each other on either side.

Legs projecting laterally from the sternum, moderately strong, 
short, 4, 1, 2, 3, furnished with hairs only; and each tarsus (so far as I could ascertain) ending with three small curved claws.

Falces small and rather weak.

Maxilla short, strong, broadest at their extremities, nearly straight.

Labium very short, broad, about half the length of the maxillæ, and slightly rounded at its apex.

Sternum somewhat quadrate in form, as though truncated behind, where it is a little narrower than in front.

Abdomen very large, globular (or, more properly, somewhat hemispherical) and projecting over the cephalothorax so as almost to conceal it when looked at from above and behind. Cuticle not coriaceous, but marked above with four small dark impressed spots in the form of a quadrangle whose anterior side is shortest.

\section{Ogulnius obtectus, sp. n. (Plate XXX. fig. 9.)}

Adult female, length $\frac{1}{24}$ of an inch.

The whole of the fore part of this minute and curious little Spider is of a dull yellow-brown colour. The cephalothorax is marked on each side by several short, wedge-shaped, converging dark-brown patches, with another stronger one on each side below the occiput. The interval between the eyes of the hind central pair is much greater than that between each and the hind lateral eye on its side, while the relative positions of the eyes of the auterior are exactly the reverse of those of the posterior row.

The abdomen is thinly clothed with short hairs, and is of a uniform somewhat vinous brownish hue. The genital aperture is of simple form, and is almost concealed by the posterior side of the sternum, which presses hard up against it. This part of the sternum has the appearance of being crushed by the operation of the large abdomen continually pressing against it, and so giving it its quadrate form. The pedicle connecting the abdomen and cephalothorax is also placed abnormally high up. The spinners are short and compact, the anterior pair being the strongest.

This genus is allied to Stegosoma, Cambr.; but the form of the maxillæ, labium, and sternum distinguishes it at a glance ; the shape of this last is very unusual, and gives rise to a quite abnormal laterigrade position of the legs.

Two examples were contained in Mr. Traill's Amazon collection, and are the smallest adult exotic Spiders I have ever yet seen, being scarcely larger than a good-sized pin's head.

\section{Tecmessa, g. n. (nom. propr.)}

Allied to Phoroncilia, Westw.; but'the caput is less drawn out, and is rather gibhous at the top of the posterior slope. Thoracic indentation large and deep.

Eyes unequal in size; the four largest form a large central quadrangle longer than broad, with the lateral pairs near on either side, their eyes respectively placed very slightly if at all obliquely; and 
the height of the clypeus (which is rather prominent) is less than half that of the facial space.

Legs moderately strong and not very long, 1, 2, 4, 3; the tibiæ of the first and second pairs bent, furnished with hairs and spines; the latter (in the type) numerous, but confined to the tibiæ, metatarsi, and tarsi of the first and second pairs. The tarsi terminate with three claws.

Falces rather short and not very strong.

Maxilla strongly bent over the labium; but both these parts of the structure are so concealed by the unusual prominence of the sternum that they could not be made out quite satisfactorily.

Sternum subtriangular, with the posterior angle strongly truncated, the truncation having the appearance of the ordinary angle bent and flattened back by constant pressure upon that part of the massive abdomen. The sternum is also very convex, so that (when the Spider is seen in profile) it projects rather below the level of the extremities of the maxillæ and falces.

Abdomen large, projecting strongly over the cephalothorax; very convex above and (especially when seen from above) looking very like that of a Gasteracantha; the integument is coriaceous and thickly clothed with small sharp-pointed scales, arranged like tiles on a roof; four sharp-pointed tubercular eminences occupy the four corners of the upperside, the posterior pair being the longest and strongest; behind them the surface is marked with strong transverse fold-like indentations, whose position is indicated by each bearing a row of dark points; two other transverse curved rows of dark points (4 and 3 ) are placed between the two posterior spine-like tubercles above noted. The spinners are short, and contained within a strong, round, sheath-like prominence.

Tecmessa pectorosa, sp. n. (Plate XXXI. fig. 10.)

Adult female, length 1 line, breadth of abdomen 1 line (nearly).

The cephalothorax is of a dark reddish yellow-brown hue, the falces, maxillæ, and sternum being rather lighter in colour; the legs also are very similar, though, excepting the femora, of a rather paler browner tinge.

The eyes are rather indistinct, all, excepting those of the fore central pair, being of an amber-brown hue.

The legs have each side of the tarsi and metatarsi, and the inner side of the tibiæ, armed with long strong spines, articulated to small tubercles, divergent and directed forward.

The habit of the Spider is, evidently, to sit with its anterior pairs of legs drawn back, bringing the spinous parts in front of and around the fore part of the caput, the spines appearing thus to protect it with an impregnable cage-like defence; or their purpose may be only to enclose and retain better within the grasp of the falces the Spider's insect prey. legs.

The palpi are rather long, and armed in a similar way to the

The sternum is one of the most remarkable features in this 
Spider; it is not only very prominent (projecting below the basal joints of the legs), but the legs of the 3rd and 4th pairs are set into it in such a way as (when looked at in profile particularly) to show a portion of it between them and the margins of the thorax. The sternum is covered with scales like the abdomen.

The abdomen is of a pale dull (though somewhat golden) yellow hue, the four sharp prominences being rather darker; the posterior part and sides are marked with curved transverse rows of small deep red-brown spots or points. The prominence supporting the spinners is dark yellow-brown; and the genital aperture is placed in a large deep-red-brown area. The whole abdomen is covered with scales (as above noted) and also with very minute bristle-like hairs, apparently one to each scale.

A single example of this remarkable Spider was contained in Mr. Traill's Amazon collection.

\section{Family MIAGRAM MOPIDA.}

Genus Miagrammopes, Cambr.

Miagrammopes trailli, sp. n. (Plate XXXI. fig. 11.)

Adult female, length $2 \frac{1}{4}$ lines.

The general form and appearance of this Spider is very similar to that of the typical species from Ceylon (described and figured Journ. Linn. Soc. x. p. 401, pl. xiv.); but its specific characters are very strong, and will serve to distinguish it at a glance from all the few species of the genus yet described.

The cephalothorax is short and of a somewhat pentagonal form, much the broadest at the eyes (giving it there an angular appearance), and truncate at its posterior extremity. At the base of the falces it is rounded; and just behind the eyes there is a very strong and deep transverse indentation.

The eyes are moderate, and not very unequal in size; they are in two pairs widely separated, each pair placed in the angle at the widest part of the caput. The eyes of each pair respectively are placed on strong black tubercles, and are near to each other, being separated by less than two diameters' interval, and forming a line nearly at right angles to the plane of the cephalothorax.

The legs of the first pair are long and strong, issuing from in front on each side just beneath the angle where the eyes are situated, and by their strength appearing to have thrust both the second pair and the palpi out of their normal places. The fourth pair are next in length and strength, but very much less in both respects than those of the first pair. The third pair are the smallest, being somewhat shorter and weaker than those of the second pair. All armature, excepting calamistra on the metatarsi of the fourth pair and the terminal tarsal claws, had been rubbed off the two examples examined. The tarsal claws are 3 ordinary ones with 2 or 3 others, supernumerary and opposed, like those in the genus Epeira. 
The colour of the cephalothorax is a dull pale yellowish brown, distinctly darkest on the sides-the legs, palpi, and falces being also of a similar hue.

The falces are small and prominent.

The palpi also are small and short.

The under surface of the cephalothorax has much more the normal appearance of a sternum than in the typical species, and is suffused with brown.

The abdomen is about twice and a half the length of the cephalothorax, and of an elongated oval form, broadest towards the spinners. It is of a pale dull yellowish-brown colour, with a still paler elongate marking along the middle of the upperside of the fore part, edged somewhat angularly with a not very distinct dark line. On the sides of and behind this marking are traces of some white markings; but the abdomen was not in sufficiently good condition to enable its colours and markings (probably in no case very strong or definite) to be satisfactorily seen.

The spinners are just beneath the posterior end of the abdomen; the ordinary ones are of moderate length, those of the inferior pair being the strongest. There is also the supernumerary spinningorgan which is always found where calamistra exist on the fourth pair of legs.

Two more or less damaged examples were received in Mr. Traill's Amazon collection.

\section{Miagrammopes longicauda, sp. n. (Plate XXXI. fig. 12.)}

Adult female, length $5 \frac{1}{2}$ lines.

In striking contrast to the species just described, this one has the cephalothorax of an oblong form rounded before, and with the sides very nearly parallel, its length being nearly double its breadth; its colour is dark but dull yellowish brown, on the sides with a rather broad longitudinal central paler band, clothed with short grey hairs.

The eyes (four in number) are small, and form a slightly curved transverse row over the caput ; the interval between the two centrals is distinctly greater than that between each and the lateral eye on its side, being equal to the breadth of the two falces.

The legs are similar in colour to the cephalothorax, and of moderate length and strength, 1, 4, 2, 3, those of the 2nd and 3rd pairs being much the shortest. They are furnished with short grey and other hairs only (these being densest on the metatarsi of the first pair); and there are the usual calamistra on the metatarsi of those of the fourth pair.

The palpi and falces are of a pale yellowish hue.

The sternal surface is deep brown ; its anterior portion is of a diamond shape, and its posterior of a triangular form, the apex of the triangle fusing in the hinder part of the anterior portion.

The abdomen is of a cylindrical form, with its posterior extremity drawn out into a pointed tail-like prolongation, two thirds or more of the length (to the spinners) of the rest of the abdomen. Its 
colour is a pale whitish yellow-brown, clothed with fine greyish hairs ; on the upperside is a long, tapering, not very distinct, narrow, blackish longitudinal central stripe; on each side is a stronger blackish-brown one ; the underside has a broad longitudinal blackishbrown central band, with a narrower stripe or line on each side of it.

The spinners are short, those of the inferior pair strongest; and immediately in front of them is the supernumerary spinning-organ characteristic of the family and genus.

Two examples of this very distinct species were contained among other Spiders found in Caffraria, and kindly given to me by Mr. J. Mansel Weale.

Miagrammopes brevicauda, sp. n. (Plate XXXI. fig. 12 a.)

Adult female, length 4 lines.

In its general colouring and appearance this Spider bears close resemblance to $M$. longicauda; but the shorter production of the posterior extremity of the abdomen distinguishes it at a glance.

The legs also are shorter, though preserving the same relative proportions and armature; and the cephalothorax is uniformly of a deep but dull brown hue, no longitudinal central paler band being discernible. The abdomen of both the examples examined were in bad condition; but there appeared to be a stronger longitudinal dark central stripe on the fore half of the upperside, and the lateral bands are wanting; the underside has a longitudinal central yellowish-brown band, margined on each side with a strong, deeper brown line. Spinners short, compact, and in other respects like those of the foregoing species. The interval between the two central eyes appears to be slightly greater than in that species, but otherwise there is not much difference in this part of their structure.

Two adult examples were received from Caffraria with those of M. longicauda.

Family Poltide.

Wixia, g. n. (nom. propr.).

Cephalothorax short, broad, sides deep and convex, lateral marginal constriction slight, profile (to beginning of hiuder slope) level. Height of clypeus considerably exceeds half that of the facial space. The caput appears to usurp the larger portion of the cephalothorax.

Eyes rather small, in three widely separated groups, a central one of four forming a small, nearly vertical quadrangle on a slight prominence of the upper part of the anterior extremity of the caput. Each of the other groups, of two nearly contiguous eyes placed horizontally, is situated far below, near the lower fore corner of the caput.

Legs short, tolerably strong, not greatly different in length, 1, 2, 4,3 ; furnished with spines on the metatarsi, tibiæ, and genual joints. The tarsi end with three claws, beneath which are one or more supernumerary opposed pectinated ones.

Falces long, powerful, conical and vertical. 
Maxilla rather long, strong, enlarged and rounded at their extremities.

Labium broad, and considerably bent in, transversely, above its connexion with the sternum; it is about half the length of the maxillæ, and somewhat pointed at the apex.

The sternum is heart-shaped, hollowed at the anterior extremity, and with slight eminences opposite to the insertions of the legs.

Abdomen short and broad, but with its anterior portion greatly elevated and produced into a long, slightly tapering, curved projection, which bends forwards over the cephalothorax.

It is probable that this genus is allied to Mastigosoma, Auss., and Cyphagogus, Günther, as well as to Poltys, C. L. Koch.

\section{Wixia abDominalis, sp. n. (Plate XXXI. fig. 13.)}

Adult female, length $3 \frac{1}{4}$ lines, length of abdomen (from the hinder extremity to the end of the anterior projection) rather over $4 \frac{1}{2}$ lines.

The cephalothorax and falces are yellow-brown; the clypeus, as well as a short, broad, oblique band towards the base of the falces, brown; the extremities of the falces deep brown; the surface of the cephalothorax is covered pretty thickly with short greyish hairs.

The eyes of the central group do not differ much in size. Those of the posterior pair are of a pale yellowish pearly colour, and seemed to be rather smaller than the anterior pair, which form, however, a shorter line, being dark-coloured and separated by no more than an eye's diameter.

The legs are dull brownish yellow, of a somewhat flattened shape, though not so much flattened as in Poltys or Corostris; besides the spines mentioned above, they are clothed with numerous greyish and other hairs. The tarsi are short.

The palpi are moderate in length and strength, and similar in colour and armature to the legs; each ends with a curved claw furnished with longish pectinations.

The maxilla and labium are dark brown tipped with whitish; and the sternum is similar in colour to the legs.

The abdomen is of a dull luteous kind of yellow-brown, clouded or suffused with a sooty-brown hue in front of the anterior elevation, of which the apex is bifid, each point ending with a round shining tubercle; on the hinder half of the abdomen are four largish impressed pit-like black spots, followed towards the spinners by two longitudinal converging rows of small diminishing deep-brown spots which look like tubercles; others, of a like nature, are disposed more or less regularly in two rows round the margins. The underside is dark sooty brown; and the genital aperture is large, with a deep red-brown shining tubercular somewhat oval prominence on each side of it. The whole abdomen is clothed with short greyish and other hairs; between the four large impressed spots on the hinder part are some blackish irregular markings.

A single example of this curious Spider was contained in $\mathrm{Mr}$. Traill's Amazon collection, and appears to me to belong to an uncharacterized genus. 


\section{Family SALT ICIDE.}

MAGo, g. n.

Cephalothorax as high behind as it is long; the posterior slope curved inwards, but almost perpendicular; profile of upperside of caput slightly conrex, and sloping a little forwards. The caput is exceedingly large, absorbing, in fact, almost the whole cephalothorax; looked at from above, its upper surface forms nearly a square; the sides also are perpendicular. Height of clypeus less than the diameter of the fore central eyes.

Ocular area slightly broader than long and equal in breadth before and behind ; fore central pair of eyes very large, and of a dull pearlgrey hue ; fore laterals in a line with base of fore centrals, and of same colour; posterior pair a little smaller than fore laterals, and as nearly as possible equally divided from them by the minute intermediate eye, which is placed a little inside of their straight line.

Legs moderately long, tolerably strong, 1, 3, 2, 4; first pair much the strongest. Armed with spines, and with a small claw-tuft beneath the terminal tarsal claws.

Falces long, straight, divergent, and directed forwards ; denticulations small; fang of moderate length and strength.

Maxilla long, strong, straight, widened on both sides at the extremities, which are rounded.

Labium long, about two thirds the length of the maxillæ, and narrower at apex than base; apex rounded. The direction of the maxillæ and labium is very nearly perpendicular (or at right angles) to the sternum, which is small, nearly round, slightly pointed behind, and truncated in front; the truncation is very gently curved, the convexity of the curve directed backwards.

Abdomen small, short-oval, very convex before, and fitting up pretty closely to the incurved thorax.

This new genus is characterized with great diffidence, and chiefly on account of the form of the cephalothorax, of which the figures (Plate XXXI.) give a fair representation. There is very little difficulty in determining a Spider to be of this family; but to which of the now numerous genera it may belong is often a very difficult point to decide. It is a very questionable addition to our knowledge of this group (which now numbers nearly 1500 species) to establish, as is now constantly being done, new genera often most closely allied, without giving a single figure either of the Spider or its generic characters. No description, however minute and laboured, can possibly, in such cases, compensate for an absence of figures. The eye takes in at a glance distinctive ideas of relative form and proportions from figures, when even the most careful description by itself would fail to give a clear conception of them.

\section{Mago intenta, sp. n. (Plate XXXI. fig. 14.)}

Adult male, length $2 \frac{1}{2}$ lines.

The cephalothorax is deep red-brown behind and on the sides, and strongly suffused with blackish on the upperside of the caput (or

Proc. Zool. Soc.-1882, No. XXX. 
ocular area). The occiput, which is paler than the rest, is clothed with greyish hairs, of which some in the centre are quite white; there is also a patch of white hairs behind each of the large fore central eyes, a smaller one almost in a line between the posterior pair of eyes, with a few similar hairs round these last. The thorax has a narrow lateral submarginal band (on each side) of white hairs; and a dense row of similar hairs projects prominently forwards just above the lower margin of the clypeus.

The legs are yellow-brown, those of the first pair, excepting the tirsi and metatarsi, much the darkest; the others are obscurely annulated with dark yellow-brown. The spines (on the first two pairs) are 4 (in two pairs) beneath the metatarsi (these are the strongest), and 6 (in three pairs) beneath the tibiæ. On the third and fourth pairs of legs the spines are more numerous, but less strong and more irregularly placed.

The palpi are moderately long; the cubital joint is of a clavate form, double the length of the radial, and has some whitish hairs on its anterior surface. The radial joint has a strong, but short, obtuse prominence behind, and a curved, shining, tapering, sharp-pointed apophysis on its outer side. The digital joint is of moderate size (but longer than the cubital), and of an oval form; the palpal organs are simple, not very prominent, and (apparently) closely surrounded with a strong black spine.

The falces, maxilla, labium, and sternum are yellow-brown; the falces are the darkest, and have, at their extremities on the inner side, two short parallel rows of small but distinct denticulations, within which the fang lies when at rest.

The abdomen is dark brownish black, varying to deep brown in parts ; on the upperside two large, somewhat crescent-shaped paler markings occupy each side of the anterior portion, and are clothed with shining white hairs ; these are obliquely crossed at their hinder ends by a similarly clothed pale stripe, thus giving the appearance of a tolerably perfect large white circle occupying the whole fore half of the upperside of the abdomen; the posterior half is marked with several ordinary pale angular bars or chevrons, thickly clothed with whitish hairs. The sides and underside are pale dull yellowish brown, the former obscurely and obliquely marked with dark brown. The spinners are small, but of tolerable and equal length and prominent.

A single example, but in very perfect condition, was received in Mr. Traill's Amazon collection.

\section{List of Spiders described.}

Xeropigo (g. n.) tridentiger, Cambr., St. Helena, p. 424, Pl. XXIX. fig. 1. Arachosia (g. n.) anyphanoides, sp. n., Amazons, p. 426, Pl. XXIX. fig. 2. Coleosoma (g. n.) blandum, sp. n., Ceylon, p. 427, Pl. XXIX. fig. 3. Sphecozone nigra, sp. n., Amazons, p. 428, Pl. XXIX. fig. 4. Achra (g. n.) insignis, sp. n., Amazons, p. 428, Pl. XXX. fig. 5. Chrysso (g. n.) albomaculata, sp. n., Amazons, p. 429, Pl. XXX. fig. 6. ? quadrata, sp. n., Ceylon, p. 430, Pl. XXX. fig. 7 . 
Thwaitesia diversa, sp. n., Amazons, p. 432, Pl. XXXI. fig. 8. affinis, sp. n., Amazons, p. 431, Pl. XXXI. fig. 8 A.

Ogulnius (g. n.) obtectus, sp. n., Amazons, p. 433, Pl. XXX. fig. 9.

Tecmessa (g. n.) pectorosa, sp. n., Amazons, p. 434, Pl. XXXI. fig. 10.

Miagrammopes traillii, sp. n., Amazons, p. 435, Pl. XXXI. fig. 11.

- longicauda, sp. n., Caffraria, p. 436, Pl. XXXI. fig. 12.

brevicauda, sp. n., Caffraria, p. 437, Pl. XXXI. fig. 12A.

Wixia (g. n.) abdominalis, sp. n., Amazons, p. 438, Pl. XXXI. fig. 13.

Mago (g. n.) intenta, sp. n., Amazons, p. 439, Pl. XXXI. fig. 14.

\section{EXPLANATION OF PLATES XXIX.-XXXI.}

Fig. 1. Xeropigo tridentiger, Cambr.

$a$, Spider without legs or palpi; $b$, ditto in profile; $c$, maxillæ, labium, and sternum; $d$, eyes from in front; $e$, left palpus on outer side; $f$, natural length of Spider.

2. Arachosia anyphenoides, sp. n.

$a$, Spider magnified; $b$, ditto in profile without legs or palpi; $c$, eyes from above and behind; $d$, maxillæ and labium; $e$, underside of abdomen; $f$, genital aperture; $g$, natural length of Spider.

3. Coleosoma blanda, sp. $\mathrm{n}$.

$a$, Spider magnified ; $b$, ditto in profile without legs or palpi ; $c$, ditto, underside; $d$, eyes from in front; $e$, right palpus on outer side; $f$, natural length of Spider.

4. Sphecozone nigra, sp. $\mathrm{n}$.

$a$, Spider in profile, without legs or palpi; $b$, left palpus, outer side.

5. Achrea insignis, sp. n.

$a$, Spider magnified ; $b$, ditto in profile without legs or palpi ; $c$, eyes from above and behind; $d$, left palpus, inner side, from below and in front; $e$, natural length of Spider.

6. Chrysso albomaculata, sp. n.

$a$, Spider ( $(+)$, enlarged; $b$, ditto $\left(\sigma^{*}\right) ; c$, ditto $(\&)$ in profile; $d$, ditto $\left(\sigma^{*}\right)$ in profile; $e$, eyes ( $\left.q\right)$, from in front; $f$, maxillæ and labium; $g$, genital aperture $(q) ; h$, right palpus $(\delta)$, from outer side; $k$, natural length of Spider $(\phi) ; m$, ditto $\left(\sigma^{*}\right)$.

7. Chrysso? quadrata, sp. n.

$a$, Spider magnified; $b$, ditto in profile; $c$, eyes, from above and behind; $d$, maxillæ, labium, and sternum; $e$, natural length of Spider.

8. Thwaitesia diversa, sp. $\mathrm{n}$.

$a$, Spider, in profile, without legs or palpi; $b$, ditto, from above; $c$, genital aperture; $d$, natural length of Spider.

8. Thwaitesia affinis, sp. n.

$a$, genital aperture.

9. Ogulnius obtectus, sp. n.

$a$, Spider magnified ; $b$, ditto in profile; $c$, caput and eyes, from in front ; $d$, underside of Spider; $e$, natural length of Spider.

10. Tecmessa pectorosa, sp. $\mathrm{n}$.

$a$, Spider magnified; $b$, ditto in profile; $c$, eyes, from above and behind ; $d$, maxillæ, labium, and sternum; $e$, natural length of Spider.

11. Miagrammopes traillii, sp. n.

$a$, Spider enlarged, without legs or palpi; $b$, ditto in profile; $c$, cephalothorax of ditto in profile, more enlarged; $d$, natural length of Spider.

12. Miagrammopes longicauda, sp. $\mathrm{n}$.

$a$, Spider enlarged, without legs or palpi ; $b$, ditto in profile; $c$, ditto natural size.

12. Miagrammopes brevicauda, sp. $\mathrm{n}$.

$a$, Spider enlarged, without legs or palpi; $b$, ditto in profile; $c$, natural length of ditto. 
Fig. 13. Wixia abdominalis, sp. n.

$a$, Spider in profile, enlarged; $b$, cephalothorax of ditto in profile; $c$, caput and eyes, from in front $; d$, abdomen, from behind ; $e$, maxillæ and labium ; $f$, natural length of abdomen to extremity of protuberance; $g$, natural length of Spider (from base of falces to just above the spinners).

14. Mago intenta, sp. n.

$a$, Spider enlarged; $b$, ditto in profile ; $c$, left palpus ; $d$, ditto, from outer side; $e$, natural length of Spider.

2. Note on an Abnormal Specimen of Pithecia satanas. By W. A. Forbes, B.A., Prosector to the Society.

[Received April 18, 1882.]

A young male specimen of Pithecia satanas, which was lately forwarded to the Society's Gardens, and died shortly after its arrival, presented an abnormal condition that is perhaps worth recording in the Society's 'Proceedings.'

The peculiarity consists in the completely " webbed" condition of the third and fourth digits of the manus on each side, these two fingers being completely connected together down to their tips by a fold of nude skin, and with their nails closely apposed, though not connected, along their contiguous margins. The other digits of the hands, as well as all of those of the feet, are quite normal, the webbing of them not extending beyond the middle of the first phalanx.

The case is interesting, partly as affording an excellent instance of an abnormal condition affecting homologous parts of opposite sides in an exactly similar way, and partly as showing that the lower Primates are subject, occasionally, to a condition of things which, as is well known, also occurs not at all rarely in Man.

3. On some Points in the Anatomy of the Todies (Todida), and on the Affinities of that Group. By W.A. Forbes, B.A., Prosector to the Society.

[Received May 15, 1882.]

One of the few important forms of birds that the late Prof. Garrod had not an opportunity, at some time or other, of dissecting was the genus Todus, the sole representative of the family Todidæ. I was therefore much gratified at being able to examine, some months ago, a spirit-specimen of Todus viridis, which was placed at my disposal for dissection by Prof. Newton with his accustomed liberality; but I hesitated to publish my notes without having further material to confirm my observations. An opportunity of doing this has lately been afforded to me by the kindness of Prof. Baird and the authorities of the Smithsonian Inst:tution in Washington, who for- 


\section{$2 \mathrm{BHL}$ Biodiversity Heritage Library}

Pickard-Cambridge, Octavius. 1882. "On new genera and species of Araneidea." Proceedings of the Zoological Society of London 1882, 423-442.

View This Item Online: https://www.biodiversitylibrary.org/item/91167

Permalink: https://www.biodiversitylibrary.org/partpdf/67444

\section{Holding Institution}

Natural History Museum Library, London

\section{Sponsored by}

Natural History Museum Library, London

\section{Copyright \& Reuse}

Copyright Status: Public domain. The BHL considers that this work is no longer under copyright protection.

This document was created from content at the Biodiversity Heritage Library, the world's largest open access digital library for biodiversity literature and archives. Visit BHL at https://www.biodiversitylibrary.org. 